\title{
The Beneficial Biological Properties of Salicylic Acid
}

\author{
Pavle Randjelović ${ }^{1}$, Slavimir Veljković ${ }^{1}$, Nenad Stojiljković ${ }^{1}$, Dušan Sokolović ${ }^{2}$ \\ Ivan Ilić ${ }^{3}$, Darko Laketić ${ }^{4}$, Dušica Randjelović ${ }^{5}$, Nebojša Randjelović6 \\ ${ }^{1}$ University of Niš, Faculty of Medicine, Department of Physiology, Niš, Serbia \\ ${ }^{2}$ University of Niš, Faculty of Medicine, Department of Biochemistry, Niš, Serbia \\ ${ }^{3}$ University of Niš, Faculty of Medicine, Institute of Pathology, Niš, Serbia \\ ${ }^{4}$ Urology Clinic, Clinical Hospital Center "Dr DragišaMišovič" -Dedinje, Belgrade, Serbia \\ ${ }^{5}$ Pediatric Clinic, Clinical Center Niš, Serbia \\ ${ }^{6}$ University of Niš, Faculty of Sport and Physical Education, Niš, Serbia
}

\begin{abstract}
SUMMARY
Salicylic acid is a phytochemical with beneficial effects on human well-being. Salicylic acid is a phenolic compound and is present in various plants where it has a vital role in protection against pathogenic agents. Natural sources include fruits, vegetables and spices. The most famous and defined effect of salicylic acid is prostaglandin synthesis inhibition. Salicylic acid has antiinflammatory effects through suppression of transcription of genes for cyclooxygenase. Most of the pharmacological properties of salicylic acid can be contributed to the inhibition of prostaglandin synthesis. Also, it was discovered that salicylic acid has other in vivo cyclooxygenase-independent pathways. Since salicylic acid does not inhibit cyclooxygenase considerably, the anti-inflammatory effect is not a consequence of direct inhibition of cyclooxygenase activity. Because of its fundamental role, it was suggested that inhibition of nuclear factor kappa B by salicylic acid is one of the key anti-inflammatory mechanisms of action for salicylates. One of the most studied properties of salicylic acid is its antioxidative activity. Salicylic acid is a confirmed inhibitor of oxidative stress. Salicylic acid is capable of binding iron. This fact is significant for antioxidative effect of salicylic acid because iron has an important function in the course of lipid peroxidation.
\end{abstract}

Key words: salicylic acid, biological activity, phytochemicals, salicylates

Corresponding author:

Pavle Randjelović

e-mail: pavleus@gmail.com 


\section{INTRODUCTION}

Salicylic acid (SA) belongs to the group of the phytochemicals with beneficial effects on human health. Salicylic acid is a phenolic compound and can be found in plants where it has a crucial role in the defense against pathogenic agents $(1,2)$. It is present in various amounts in fruits, vegetables and spices. It is more popular as the main metabolite and active component of acetyl salicylic acid (ASA), an antiinflammatory drug used in clinical practice for more than 100 years (3). In the last decade it has been accepted that chronic intake of ASA in low doses can be effective in the prevention of cardiovascular disease (CVD) and colorectal carcinoma $(4,5)$. This fact supports the hypothesis that beneficial health effects of fruits and vegetables partially depends on the presence of SA in it. Salicylic acid can be detected in the blood of normal, healthy population without record of ASA usage, suggesting the origin from plant-based food (6).

The analgesic effect of willow bark has been known since Hippocrates first described it. It was used through history in traditional medicine for treating pain. In the year 1859, an active component, SA, was isolated and synthesized. SA is crystal organic carboxylic acid. It is soluble in alcohol, while poorly soluble in water. Since it has a damaging effect on gastric mucosa, in 1897 Felix Hoffman synthesized buffered form ASA (7).

\section{INHIBITION OF PROSTAGLANDIN SYNTHESIS}

The most investigated and described effect of SA is the inhibition of the synthesis of prostaglandins (PGs)(8). PGs are members of the lipid family and are produced from polyunsaturated fatty acids by enzyme cyclooxygenase (COX). Almost all the cells in the human body can make PGs from arachidonic acid which is present in the cell membrane phospholipids. After being synthesized, PGs act as autocrine or paracrine lipid mediators in maintaining local homeostasis in the organism. Prostaglandins have numerous physiological functions like: a) protection of the gastrointestinal tract; b) regulation of the kidney homeostasis; c) regulation of sleep and wakening and d) regulation of body temperature (9). The synthesis of PGs is generally very small in tissues without inflammation. On the other hand, during the process of inflammation there is a marked change in the concentration and type of PGs.

First, it was considered that SA inhibits the synthesis of PG through COX inhibition (10). However, in 1999, a new pathway of PG inhibition was proposed for SA and ASA. Xu et al. (11) showed that SA and ASA act anti-inflammatory by suppressing transcription of genes for COX. Most of the pharmacological effects of SA can be explained by PG synthesis inhibition. Also, it was described that SA has other COX-independent mechanisms of action (12).

\section{ANTI-INFLAMMATORY EFFECTS}

It is considered that SA and ASA have equal anti-inflammatory properties (13). Since SA does not inhibit COX considerably, the anti-inflammatory effect is not mediated through direct inhibition of COX activity. Moreover, ASA has a short half-life in the blood. ASA is deacetylated to form SA, which is responsible for in vivo effects. It was shown that antiinflammatory action of SA is mediated by the inhibition of leukocyte function and inhibition of the expression of different proinflammatory genes (14).

Inducible nitric oxide synthase (iNOS) has an important role in the process of inflammation and tissue injury. Similarly to COX-2, the expression of iNOS is induced by cytokines and lipopolysaccharide (LPS). This enzyme catalyzes the production of nitric oxide (NO) which acts further by activation of guanylate cyclase as well as by nitration and nitrosylation of proteins. Furthermore, NO reacts with superoxide anion and creates peroxynitrite. Peroxynitrite is highly reactive and is capable of damaging cells. It was shown that SA inhibits expression of iNOS stimulated by LPS and interferon gamma (IFN $\gamma)$ in alveolar macrophages of rats (15, 16). Ruy et al .(17) described the suppression of iNOS by SA in RAW 264.7 cells at post-translational or translational level but not at the level of transcription. Sakitani et al. (18) also demonstrated the inhibition of iNOS expression by SA in hepatocytes at the level of translation but not transcription.

Even though the most studies showed that SA inhibits the expression of iNOS in pharmacological doses, there were some reports with similar results only with supratherapeutic doses (19). Paradoxically, Nishio et al. (20) showed the opposite effect of SA to iNOS expression. They found that sodium salicylate increases the synthesis of iNOS and NO in vascular smooth muscle cells, although the observed effect was 
weak. These contradictory findings suggest that the effect of SA on iNOS expression depends on cell type, experimental conditions and stimulation.

Sodium salicylate has proved itself as successful in suppression of acute inflammatory reactions in animals (21). Abramson et al. (13) showed that ASA inhibits neutrophil function. It was suggested that it was a consequence of adenosine synthesis induction (22). The results from recent study have indicated that SA can reduce oxidative-stress associated renal injury by reducing oxygen free radicals and lipid peroxidation in gentamicin-treated rats (23).

\section{NUCLEAR FACTOR KAPPA B INHIBITION}

It is known that high concentration of SA can react with kinases, including mitogen activated protein kinase (MAPK). Most authors point out that the reaction of SA with kinases is inhibitory. It can be one of the reasons for inhibitory effects of SA on several nuclear transcription factors. Among transcription factors, the research focus is on the interaction between SA and nuclear factor kappa $b$ $(\mathrm{NF}-\kappa \mathrm{B})$. The mentioned nuclear factor is a key element in cellular response to inflammatory stimulus. The inhibition of NF- $\mathrm{BB}$ by SA was first reported by Kopp and Ghosh in 1994 (24) and in many experiments later on $(25,26)$. Since NF- $\kappa B$ regulates the expression of pro-inflammatory enzymes, cytokines, chemokines, receptors and cell adhesion molecules, it is usually named as central mediator of immune response (27). Because of its central role, it was proposed that inhibition of NF- $\kappa B$ by $\mathrm{SA}$ is one of the main anti-inflammatory mechanisms of action for salicylates (24).

Nuclear factor kappa B is involved in the control of transcription of many genes not involved in immune response. That is why NF- $k B$ is more a regulator of response to stress than central mediator of immune response. Nuclear factor kappa B also functions as apoptosis regulator, either as inductor or, more often, as the inhibitor of programmed cell death. The final effect of NF- $\kappa B$ on apoptosis depends on cell type and inductor type. Nuclear factor kappa B transcription factors are regulated primarily by interaction with inhibitory I $\kappa B$ proteins. In most cells, $\mathrm{NF}-\kappa \mathrm{B}$ is in cytoplasm in inactive form bound to $\mathrm{I} \kappa \mathrm{B}$. Most NF- $\kappa \mathrm{B}$ activators proteolyze I $\mathrm{B}$. The released
$\mathrm{NF}-\kappa \mathrm{B}$ is then transferred to the nucleus where it binds to $\kappa B$ region in promoter of target genes and regulates transcription. Stimulation of cells by LPS in the presence of SA resulted in the lack of LPS-induced proteolysis of $I \kappa B$, which proved that the observed inhibition of NF- $\mathrm{KB}$ is mediated by inhibition of phosphorylation and/or proteolysis of I $\kappa$ B (24). The serum concentrations of SA between 1 and $2 \mathrm{mM}$ are necessary for anti-inflammatory effects, while concentrations higher than $6 \mathrm{mM}$ are toxic (28).

\section{ANTIOXIDATIVE PROPERTIES}

One of the most studied characteristic of SA is its antioxidative property. Since SA is used as a chemical trap for hydroxyl radical, it was reported that SA could reduce tissue damage caused by hypoxia/reoxygenation (29). However, it is not quite clear if antioxidative property of SA has the influence on its anti-inflammatory effects.

For example, the effect of SA on neutrophils adhesion can be explained by the inhibition of extracellular MAPK activation necessary for integrin activity (30). Also, it was shown that SA inhibits the activation of transcription factors like NF-kB (24). One of the studies has described a new pharmacological effect of SA as the inhibition of transcription for several cytokines genes (31). Therefore, it is possible that there are additional, undiscovered mechanisms of action of SA.

Salicylic acid is a verified inhibitor of oxidative stress. Sagone et al. (32) showed that SA reacted with hydroxyl radicals in granulocytes and created metabolites. Also, SA decreased superoxide anion radicals by acting on NADPH activity which decreased reactive oxygen species (ROS) in human endothelial cells in vitro (33). Salicylic acid can bind iron $\left(\mathrm{Fe}^{2+}\right)(34)$. This fact is important because $\mathrm{Fe}^{2+}$ has an important function in the process of lipid peroxidation. The iron creates not only $\mathrm{OH}^{-}$through Fenton reaction but is involved in the creation of peroxy and alkoxy radicals (35).

\section{CONCLUSION}

There is no doubt that SA is an important natural compound widely available in nature with proven and described beneficial biological properties. According to some authors, salicylic acid deserves an 
epithet of a vitamin, "Vitamin S". Most of the literature-based data about SA is from studies dealing with disease preventive properties of ASA. Even though SA is the main in vivo metabolite of ASA, we cannot equalize the effect of those two related molecules inside the human body. On the other hand, natural sources of SA like plants are also loaded with other health-promoting phytochemical which can be present in higher quantities. Some of them share described biological effects of SA. In this context, we should not draw straightforward conclusions about SA and human health. Finally, we can conclude that SA is a potent and important naturally occurring phytochemical with numerous health-promoting effects, but further experimental studies using isolated SA are needed to fully understand its biological effects.

\section{Acknowledgements}

This work was supported by the Ministry of Science and Technological Development, Republic of Serbia (grants 43012 and 172061).

\section{References}

1. Dempsey DA, Klessing DF. Salicylic acid, active oxygen species and system acquired resistance in plants. Trends Cell Biol 1994; 4:334-8.

http://dx.doi.org/10.1016/0962-8924(94)90235-6

2.Dangl J. Innate immunity.Plant just say $\mathrm{NO}$ to pathogens. Nature 1998; 394:525-7.

http://dx.doi.org/10.1038/28958

3. Stanley P, Hegedus R. Aspirin - the first hundred years. Biologist 2000; 47: 269-71.

4. Sanmuganathan PS, Ghahramani P, Jackson PRet al. Aspirin for primary prevention of coronary heart disease: safety and absolute benefit related to coronary risk derived from meta-analysis of randomised trials. Heart 2001; 85: 265-71.

http://dx.doi.org/10.1136/heart.85.3.265

5. Gasche C. Review Article: The chemoprevention of colorectal carcinoma. Aliment Pharmacol Ther 2004; 20: 31-35.

http://dx.doi.org/10.1111/j.1365-2036.2004.02045.x

6. Duthie GG, Wood AD.Natural salicylates: foods, functions and disease prevention. Food Funct 2011; 2:515-520.

http://dx.doi.org/10.1039/c1fo10128e

7. Schindler PE Jr, Fields WS. Aspirin Therapy. Walker and Company,New York, 1978.

8. Vane JR. Inhibition of prostaglandin synthesis as a mechanism of action for aspirin-like drugs. Nat New Biol 1971; 231:232-235.

http://dx.doi.org/10.1038/newbio231232a0
9. Murray RK, Granner DK, Mayes PA, Rodwell VW. Harper's Biochemistry.21 ${ }^{\text {st }}$ edn.Appleton \& Lange, Norwalk, 1988.

10. Ohki S, Ogino N, Yamamoto S, Hayaishi O. Prostaglandin hydroperoxidase, an integral part of prostaglandin endoperoxidesynthetase from bovine vesicular gland microsomes. J Biol Chem 1979; 254:829-36.

11. Xu XM, Sansores-Garcia L, Chen XM, MatijevicAleksic N, Du M, Wu KK.Suppression of inducible cyclooxygenases-2 gene transcription by aspirin and sodium salicylate. Proc Natl Acad Sci USA 1999; 96:5292-5297. http://dx.doi.org/10.1073/pnas.96.9.5292

12. Tegeder I, Pfeilschifter J, Geisslinger G. Cyclooxygenase-independent actions of cyclooxygenase inhibitors. FASEB J 2001; 15:2057-2072.

http://dx.doi.org/10.1096/fj.01-0390rev

13. Abramson SB, Leszczynska-Piziak J, Clancy RM, Philips M, Weissmann G. Inhibition of neutrophil function by aspirin-like drugs (NSAIDS): requirement for assembly of heterotrimeric G proteins in bilayer phospholipid. Biochem Pharmacol 1994; 47:563572.

http://dx.doi.org/10.1016/0006-2952(94)90189-9

14. Abramson SB, Weissmann G. The mechanisms of action of nonsteroidal antiinflammatory drugs. Arthritis Rheum 1989; 32:1. 
http://dx.doi.org/10.1002/anr.1780320102

15. Aeberhard EE, Henderson SA, Arabolos NS et al. Nonsteroidal anti-inflammatory drugs inhibit expression of the inducible nitric oxide synthase gene. Biochem Biophys Res Commun 1995; 208:1053-1059.

http://dx.doi.org/10.1006/bbrc.1995.1441

16. Kepka-Lenhart D, Chen LC, Morris SM. Novel actions of aspirin and sodium salicylate: discordant effects on nitric oxide synthesis and induction of nitric oxide synthase mRNA in a murine macrophage cell line. J Leukoc Biol 1996; 59:840-6.

17.Ryu YS, Lee JH, Seok JH et al. Acetaminophen inhibits iNOS gene expression in RAW 264.7 macrophages: differential regulation of $\mathrm{NF}$ kappaB by acetaminophen and salicylates. Biochem Biophys Res Commun 2000; 272:758-64. http://dx.doi.org/10.1006/bbrc.2000.2863

18. Sakitani $\mathrm{K}$, Kitade $\mathrm{H}$, Inoue $\mathrm{K}$ et al. The antiinflammatory drug sodium salicylate inhibits nitric oxide formation induced by interleukin1beta at a translational step, but not at a transcriptional step, in hepatocytes. Hepatology 1997; 25:416-420.

http://dx.doi.org/10.1002/hep.510250226

19.Chung CK, Koo HN, Chung KY et al. Inhibitory effect of sodium salicylate on nitric oxide production from TM4 sertoli cells.Int J Immunopharmacol 2000; 22:685-692. http://dx.doi.org/10.1016/S0192-0561(00)00031-X

20. Nishio E, Watanabe Y. Aspirin and salicylate enhances the induction of inducible nitric oxide synthase in cultured rat smooth muscle cells. Life Sci 1998; 63:429-439.

http://dx.doi.org/10.1016/S0024-3205(98)00292-6

21. Cronstein BN, Montesinos MC, Weissmann G. Salicylates and sulfasalazine, but not glucocorticoids, inhibit leukocyte accumulation by an adenosine-dependent mechanism that is independent of inhibition of prostaglandin synthesis and p105 of NFkB. Proc Natl Acad Sci USA 1999; 96:6377-6381.

http://dx.doi.org/10.1073/pnas.96.11.6377
22. Catania A, Arnold J, Macaluso A, Hiltz ME, Lipton JM. Proc Natl Acad Sci USA 1991; 88:8544-8547.

http://dx.doi.org/10.1073/pnas.88.19.8544

23. Randjelovic P, Veljkovic S, Stojiljkovic N et al. Salicylic acid attenuates gentamicin-induced nephrotoxicity in rats. Scientific World Journal 2012; 2012:390613.

http://dx.doi.org/10.1100/2012/390613

24. Kopp E, Ghosh S. Inhibition of NF-kappa B by sodium salicylate and aspirin. Science 1994; 265:956-9.

http://dx.doi.org/10.1126/science. 8052854

25. Yin MJ, Yamamoto Y, Gaynor RB. The antiinflammatory agents aspirin and salicylate inhibit the activity of I(kappa)B kinase-beta. Nature 1998; 396:77-80.

http://dx.doi.org/10.1038/23948

26. Bayon Y, Alonso A, Sanchez Crespo M. 4Trifluoromethyl derivatives of salicylate, triflusal and its main metabolite 2-hydroxy-4trifluoromethylbenzoic acid, are potent inhibitors of nuclear factor kappaB activation. $\mathrm{Br}$ J Pharmacol 1999; 126:1359-66. http://dx.doi.org/10.1038/sj.bjp.0702441

27. Pahl HL. Activators and target genes of Rel/NFkappaB transcription factors. Oncogene1999; 18:6853-66. http://dx.doi.org/10.1038/sj.onc.1203239

28. Cianferoni A, Schroeder JT, Kim J et al. Selective inhibition of interleukin-4 gene expression in human T cells by aspirin. Blood 2001; 97:17421749 .

http://dx.doi.org/10.1182/blood.V97.6.1742

29. Colantoni A, de Maria N, Caraceni P, Bernardi M, Floyd RA, Van Thiel DH. Prevention of reoxygenation injury by sodium salicylate in isolated-perfused rat liver. Free Radic Biol Med 1998; 25:87-94.

http://dx.doi.org/10.1016/S0891-5849(98)00033-1

30. Pillinger $\mathrm{MH}$, Capodici $\mathrm{C}$, Rosenthal $\mathrm{P}$ et al. Modes of action of aspirin-like drugs: salicylates inhibit erk activation and integrin-dependent neutrophil adhesion. Proc Natl Acad Sci U.S.A 1998; 95:14540-14545. 
http://dx.doi.org/10.1073/pnas.95.24.14540

31. Aceves M, Duenas A, Gomez C, San Vicente E, Crespo MS, Garcia-Rodriguez C. A new pharmacological effect of salicylates: inhibition of NFAT-dependent transcription. J Immunol 2004; 173:5721-5729.

http://dx.doi.org/10.4049/jimmunol.173.9.5721

32. Sagone AL Jr, Husney RM. Oxidation of salicylates by stimulated granulocytes: evidence that these drugs act as free radical scavengers in biological systems. J Immunol 1987; 138:2177-83.

33. Dragomir E, Manduteanu I, Voinea M, et al. Aspirin rectifies calcium homeostasis, decreases reactive oxygen species, and increases NO production in high glucose-exposed human endothelial cells. J Diabetes Complications 2004; 18:289-99.

http://dx.doi.org/10.1016/j.jdiacomp.2004.03.003

34. Kotrly S, Sucha L. Handbook of Chemical Equilibria in Analytical Chemistry. Ellis Horwood Limited, Chichester, 1985.

35. Halliwell B, Gutteridge JMC. Role of free radicals and catalytic metal ions in human disease: an overview. In: Packer L, Glazer AN (eds), Methods Enzymol, vol. 186. Academic Press, California, 1990: 1-5.

http://dx.doi.org/10.1016/0076-6879(90)86093-b 


\title{
Povoljna biološka svojstva salicilne kiseline
}

\author{
Pavle Ranđelović ${ }^{1}$, Slavimir Veljković1, Nenad Stojiljković1, Dušan Sokoloviće, \\ Ivan Ilić ${ }^{3}$, Darko Laketić ${ }^{4}$ Dušica Ranđelovićs, Nebojša Ranđelović ${ }^{6}$ \\ ${ }^{1}$ Univerzitet u Nišu, Medicinski fakultet, Institut za fiziologiju, Niš, Srbija \\ ${ }^{2}$ Univerzitet u Nišu, Medicinski fakultet, Institut za biohemiju, Niš, Srbija \\ ${ }^{3}$ Univerzitet u Nišu, Medicinski fakultet, Institut za patologiju, Niš, Srbija \\ ${ }^{4}$ Klinika za urologiju, Koliničko-bolnički centar "Dr Dragiša Mišović - Dedinje", Beograd, Srbija \\ ${ }^{5}$ Klinika za dečije interne bolesti, Klinički centar Niš, Niš, Niš, Srbija \\ ${ }^{6}$ Univerzitet u Nišu, Fakultet sporta i fizičkog vaspitanja, Niš, Srbija
}

\section{SAŽETAK}

Salicilna kiselina je fitohemikalija sa povoljnim efektima na ljudsko zdravlje. Salicilna kiselina je fenolna komponenta i prisutna je u različitim biljkama, gde ima važnu ulogu u zaštiti od patogenih agenasa. U prirodi se nalazi u voću, povrću i začinima. Najpoznatiji i najbolje proučen efekat salicilne kiseline je inhibicija sinteze prostanglandina. Salicilna kiselina ostvaruje anti-zapaljensko dejstvo preko supresije gena za ciklooksigenazu. Većina farmakoloških svojstava salicilne kiseline mogu se objasniti inhibicijom sinteze prostanglandina. Otkriveno je da salicilna kiselina pored ovog ima i druga in vivo dejstva. Pošto salicilna kiselina ne inhibira značajno ciklooksigenazu, anti-zapaljensko dejstvo nije posledica direktne inhibicije ovog enzima. Predloženo je da je inhibicija nuklearnog faktora kapa B od strane salicilata jedno od glavnih mehanizama anti-zapaljenskog dejstva salicilata. Jedno od najviše proučavanih svojstava salicilne kiseline je antioksidativna aktivnost. Salicilna kiselina je dokazani inhibitor oksidativnog stresa. Salicilna kiselina ima sposobnost vezivanja gvožđa. Ova činjenica je značajna za antioksidativno dejstvo salicilne kiseline zbog toga što gvožđe ima važnu ulogu u procesu lipidne peroksidacije.

Ključne reči: salicilna kiselina, biološka aktivnost, fitohemikalije, salicilati 